\title{
SPORE VIABILITY OF MICROSPORIDIAN SPECIES ISOLATED FROM GYPSY MOTH LARVAE (LYMANTRIA DISPAR) AFTER LONG-TERM STORAGE IN LIQUID NITROGEN
}

\section{VITALNOST SPORA MIKROSPORIDIJA IZOLIRANIH IZ GUSJENICA GUBARA (Lymantria dispar) NAKON DUGOTRAJNE POHRANE U TEKUĆEM DUŠIKU}

Daniela PILARSKA ${ }^{1,2}$, Manana KERESELIDZE ${ }^{3,4}$, Gernot $\mathrm{HOCH}^{5}$, Andreas LINDE ${ }^{6}$

\begin{abstract}
SUMMARY
Data on the viability of microsporidian isolates from Lymantria dispar after long-term storage in liquid nitrogen are presented. Eight microsporidian isolates from $L$. dispar were tested for their infectivity against $L$. dispar larvae: Vairimorpha disparis, Nosema lymantriae, Nosema portugal, Nosema sp. (Poland), Nosema sp. (Ebergassing), Nosema sp. (Germany), Nosema sp. (Schweinfurt) and Nosema sp. (Veslec). The survival of spores in liquid nitrogen was studied in detail for N. portugal and Nosema sp. (Ebergassing) which had been stored in liquid nitrogen almost 19 years and used for individual per oral infections while the other six isolates were used only in surface contamination per oral experiments. Our study confirms that storage in liquid nitrogen is a suitable option for long-term storage of Nosema and Vairimorpha species from lepidopteran hosts. Spores survived for up to 19 years; however, the experiments show that there is a significant loss of viability. In some cases, spores had lost viability already after 7 years in liquid nitrogen. We recommend producing fresh material every 5 years to maintain collections in liquid nitrogen. No material that had been stored in liquid nitrogen for extended periods should be used for infection experiments.
\end{abstract}

KEY WORDS: microsporidia, spore viability, long-term storage, liquid nitrogen

\section{INTRODUCTION}

UVOD

Microsporidia are single-cell pathogens related to the Fungi, infecting animal hosts from all major taxa. Insects are the most commonly reported hosts and at least 80 microsporidian genera are known from insect hosts. As primary pathogens, microsporidia often play an important role in the regulation of insect populations (Solter et al., 2012). Effects of infection are generally rather chronic, leading to only low or moderate mortality (Hoch and Solter, 2018). Microsporidian infection frequently decreases host reproduction and feeding, and epizootics in the host population can reduce populations and, thus, damage to host

\footnotetext{
1 Prof. Dr. Daniela Pilarska, Department of Natural Sciences, New Bulgarian University, Montevideo Str. 21, 1618 Sofia, Bulgaria ${ }^{2}$ Institute of Biodiversity and Ecosystem Research, Bulgarian Academy of Sciences, Tsar Osvoboditel 1, 1000 Sofia, Bulgaria

${ }^{3}$ Dr. Manana Kereselidze, Scientific-Research Center of Agriculture, Marshal Gelovani Ave 6, 0159 Tbilisi, Georgia

${ }^{4}$ Vasil Gulisashvili Forest Institute, Agricultural University of Georgia, 240 David Aghmashenebeli Alley, 0159 Tbilisi, Georgia

${ }^{5}$ Priv. Doc. Dr. Gernot Hoch, Department of Forest Protection, Austrian Research Centre for Forests (BFW), Seckendorff-Gudent-Weg 8, 1131 Vienna, Austria

${ }^{6}$ Prof. Dr. Andreas Linde, Eberswalde University for Sustainable Development, Alfred-Möller-Str. 1, 16225 Eberswalde, Germany
} 
plants. Occasionally, microsporidia are noticed as important mortality factors in outbreak populations of the gypsy moth, Lymantria dispar. Reports of high prevalence of infections by these pathogens exist e.g. from Sardinia, Poland, the Ukraine (McManus and Solter, 2003, Solter et al., 2012). More typically, however, they seem to occur at lower enzootic level and can be found in most populations when a thorough screening is done (Novotny, 1989; Hoch et al., 2001; Pilarska et al., 1998; 2006). Other examples of microsporidian species that have significant adverse effects on forest insect pests are Nosema fumiferanae in the spruce budworm, Choristoneura fumiferana, and Nosema tortricis in Tortrix viridana (Solter et al., 2012).

For over 20 years, the gypsy moth, Lymantria dispar, which is a major pest in the broadleaf forests of Europe, Asia, Northern Africa, and its invaded area in North America, was the focus of a group of insect pathologists from Europe (Germany, Austria, Slovakia, Czech Republic, Bulgaria, Georgia) and the United States. As a result of this cooperation, three species of microsporidia and more than 25 microsporidian isolates were recovered from European populations of the gypsy moth (Pilarska et al., 1998; Solter et al., 2000; Vavra et al., 2006; Solter et al., 2010). The life history, morphology, host tissue specificity, virulence and persistence, and biology of several of these microsporidia have been intensively studied to elucidate interactions with the host and to facilitate decisions regarding use in biological control programs (Solter et al., 2000; 2002; Goertz et al., 2004; Vavra et al., 2006; Pilarska et al., 2006; Solter et al., 2010; Pilarska et al., 2017; Hoch and Solter, 2018).

The necessity for in-vivo production in host insects and the slow progress of disease put constraints on the use as biological pesticides applied in inundative releases. Only one microsporidian species, Paranosema (Nosema) locustae, is commercially produced for control of grasshoppers and crickets (Bjørnson and Oi, 2014). Inoculative releases to augment epizootics or into naïve host populations to initiate establishment - also in classical biological control programs - appear more promising for a wider variety of insects (Hoch and Solter, 2018). There have been experimental releases against the gypsy moth in Slovakia, Bulgaria and in the United States using the microsporidia Nosema lymantriae and Vairimorpha disparis (Weiser and Novotny, 1987, Jeffords et al., 1988; Jeffords et al., 1989; Solter et al., 2010). Results from a 3-year monitoring of two experimental populations in Bulgaria showed that N. lymantriae was established after introduction and its prevalence varied from 3.5 to $33.0 \%$ (Pilarska et al., 2010).

An important issue for both, studies of microsporidia and production of material for biological control, is the storage of viable material for extended periods. Maddox and Solter (1996) showed that storage of microsporidian spores from terrestrial insect hosts in liquid nitrogen reduces the loss of infectivity and recommend such storage. Consequently, many studies of pathogen biology and host-parasite interaction became possible because all collected microsporidian isolates from gypsy moth were available in liquid nitrogen storage in several laboratories in the US and Europe. For applied research, like experimental infections or for the use in biological pest control applications, a collection of isolates with infective spores is essential.

In this paper we present data about the viability of different microsporidian isolates from $L$. dispar after long-term storage in liquid nitrogen for periods between 7 to 18 years and 9 months.

\section{MATERIAL AND METHODS MATERIJALI I METODE}

\section{a) Microsporidia - Mikrosporidije}

Microsporidian spores from the microsporidia collection at the laboratory of A. Linde, Eberswalde University of Sustainable Development, Germany were used in our experiments. All spores had been stored in a liquid nitrogen dewar flask for at least 7 years. The filling level of the storage tank is checked every 14 days to ensure that all samples are covered with liquid nitrogen at all times. A refill with liquid nitrogen is necessary 3 to 4 times per year. Stored microsporidian spores had been harvested from laboratory infected $L$. dispar larvae following a standard protocol: For production of clean material, the infested tissues, such as fat body or silk glands, were dissected out of larvae. The tissue was homogenized in distilled water in a tissue grinder, filtered through cellulose tissue and centrifuged. The spore pellet was re-suspended in distilled water and mixed 1:1 with glycerol. $1 \mathrm{ml}$ of the suspension was filled into a cryo vial and submerged in liquid nitrogen in the dewar. The spore suspensions tested in this study had never been removed from the dewar throughout the storage period until used in the experiment.

\section{b) Surface contamination experiment - Test kontaminacije hranjivog supstrata}

Eight microsporidian isolates from $L$. dispar were tested for their infectivity against $L$. dispar larvae: Vairimorpha disparis, Nosema lymantriae, Nosema portugal, Nosema sp. (Poland), Nosema sp. (Ebergassing), Nosema sp. (Germany), Nosema sp. (Schweinfurt) and Nosema sp. (Veslec). Vials containing spore suspensions of the test isolates in concentrations higher than $1 \times 10^{5}$ spores $/ \mu$ were removed from liquid nitrogen and thawed at room temperature. The spores were cleaned from the glycerol by repeated centrifugation and re-suspension in distilled water. Then, $1 \mathrm{ml}$ of spore suspension was evenly spread on the surface 
of meridic wheat germ diet that had been poured into $250 \mathrm{ml}$ plastic cups.

L. dispar were obtained from egg masses provided by the USDA-APHIS Otis Method Development Center, Massachusetts, USA, and reared on meridic wheat germ diet in 250 -ml plastic cups at $24^{\circ} \mathrm{C}, 16 \mathrm{~h} \mathrm{light} / 8 \mathrm{~h}$ dark. Twenty larvae in $2^{\text {nd }}$ day of $3^{\text {rd }}$ instar were transferred into each of the diet cups treated with microsporidia and were reared for 20 days. At the end of the incubation period, all larvae were dissected individually and inspected under light microscope for the presence of microsporidia to confirm infection.

\section{c) Individual infections - Individualne infekcije}

The spore viability in liquid nitrogen was studied in more detail for Nosema portugal and Nosema sp. (Ebergassing); spores of these isolates had been stored in liquid nitrogen for 19 years.

Spores were prepared as described above and adjusted to three different concentrations - $100 \mathrm{sp} / \mu \mathrm{l}, 1000 \mathrm{sp} / \mu \mathrm{l}$ and $10000 \mathrm{sp} / \mu \mathrm{l}$. Blocks of the wheat germ diet cut to $4 \mathrm{~mm}^{3}$ were placed individually into the wells of tissue cultures 24 wells plates and $1 \mu \mathrm{l}$ of spore suspension was applied to the surface of each block. Second day third instar larvae that starved for $24 \mathrm{~h}$ before infection were placed individually into each well. Each larva that consumed the whole diet block within $24 \mathrm{~h}$ was used in the experiments. Controls were treated in the same manner; however, the diet blocks were inoculated with distilled water.

Totally $336 \mathrm{~L}$. dispar larvae were used in this experiment, 48 larvae in each treatment. Larvae were reared individually in $30 \mathrm{ml}$ diet cups at $24^{\circ} \mathrm{C}$ until 25 th day post infection. At the end of the incubation period, all larvae were dissected individually and inspected under light microscope for the presence of microsporidia to confirm infection.

\section{RESULTS}

\section{REZULTATI}

\section{a) Surface contamination experiment - Test kontaminacije hranjivog supstrata}

From the 8 microsporidian isolates used for surface contamination, only 4 isolates - Vairimorpha disparis, Nosema lymantriae, Nosema sp. (Ebergassing), and Nosema sp. (Poland) - produced infections in the challenged $L$. dispar larvae (Table 1). While all test larvae (100\%) were infected with the first three mentioned isolates, only $21.1 \%$ of the test larvae exposed to spores of Nosema sp. (Poland) were infected. At the end of the incubation period, all dissected larvae infected with the four isolates showed signs of a heavy infection; tissues were filled with environmental spores.
Table 1. Infectivity of isolates stored in liquid nitrogen for infections Tablica 1. Infektivnost testiranih izolata pohranjenih u tekućem dušiku

\begin{tabular}{|c|c|c|c|}
\hline $\begin{array}{l}\text { Microsporidian } \\
\text { isolate } \\
\text { Mikrosporidijski } \\
\text { izolat }\end{array}$ & $\begin{array}{c}\text { Country } \\
\text { of origin } \\
\text { Zemlja } \\
\text { porijekla }\end{array}$ & $\begin{array}{l}\text { Duration of storage in } \\
\text { liquid nitrogen and } \\
\text { spore concentration } \\
\text { Vrijeme pohrane u } \\
\text { tekućem dušiku i } \\
\text { koncentracija spora }\end{array}$ & $\begin{array}{l}\text { Percent of } \\
\text { larvae } \\
\text { infected (\%) } \\
\text { Postotak } \\
\text { inficiranih } \\
\text { ličinki (\%) }\end{array}$ \\
\hline $\begin{array}{l}\text { Vairimorpha } \\
\text { disparis }\end{array}$ & $\begin{array}{c}\text { Bulgaria } \\
\text { Bugarska }\end{array}$ & $\begin{array}{c}93 \text { months } \\
93 \text { mjeseca } \\
>1 \times 10^{6} \mathrm{sp} / \mu \mathrm{l}\end{array}$ & 100 \\
\hline $\begin{array}{l}\text { Nosema } \\
\text { lymantriae } \\
\text { (Levishte) }\end{array}$ & $\begin{array}{l}\text { Bulgaria } \\
\text { Bugarska }\end{array}$ & $\begin{array}{c}93 \text { months } \\
93 \text { mjeseca } \\
>1 \times 10^{6} \mathrm{sp} / \mu \mathrm{l}\end{array}$ & 100 \\
\hline $\begin{array}{l}\text { Nosema } \\
\text { portugal }\end{array}$ & $\begin{array}{l}\text { Portugal } \\
\text { Portugal }\end{array}$ & $\begin{array}{l}225 \text { months } \\
225 \text { mjeseci } \\
8.8 \times 10^{5} \mathrm{sp} / \mu \mathrm{l}\end{array}$ & 0 \\
\hline $\begin{array}{l}\text { Nosema sp. } \\
\text { (Poland) }\end{array}$ & $\begin{array}{l}\text { Poland } \\
\text { Poljska }\end{array}$ & $\begin{array}{c}93 \text { months } \\
93 \text { mjeseca } \\
>1 \times 10^{5} \mathrm{sp} / \mu \mathrm{l}\end{array}$ & 21.1 \\
\hline $\begin{array}{l}\text { Nosema sp. } \\
\text { (Ebergassing) }\end{array}$ & $\begin{array}{l}\text { Austria } \\
\text { Austrija }\end{array}$ & $\begin{array}{l}225 \text { months } \\
225 \text { mjeseci } \\
2.1 \times 10^{5} \mathrm{sp} / \mu \mathrm{l}\end{array}$ & 100 \\
\hline $\begin{array}{l}\text { Nosema sp. } \\
\text { (Germany) }\end{array}$ & $\begin{array}{l}\text { Germany } \\
\text { Njemačka }\end{array}$ & $\begin{array}{c}129 \text { months } \\
129 \text { mjeseci } \\
>1 \times 10^{5} \mathrm{sp} / \mu \mathrm{l}\end{array}$ & 0 \\
\hline $\begin{array}{l}\text { Nosema sp. } \\
\text { (Schweinfurth) }\end{array}$ & $\begin{array}{l}\text { Germany } \\
\text { Njemačka }\end{array}$ & $\begin{array}{c}92 \text { months } \\
92 \text { mjeseca } \\
>1 \times 10^{5} \mathrm{sp} / \mu \mathrm{l}\end{array}$ & 0 \\
\hline $\begin{array}{l}\text { Nosema sp. } \\
\text { (Veslec) }\end{array}$ & $\begin{array}{l}\text { Bulgaria } \\
\text { Bugarska }\end{array}$ & $\begin{array}{c}129 \text { months } \\
129 \text { mjeseci } \\
>1 \times 10^{6} \mathrm{sp} / \mu \mathrm{l}\end{array}$ & 0 \\
\hline
\end{tabular}

\section{b) Individual infection - Individualne infekcije}

Microscopic evaluations of the L. dispar larvae individually infected with Nosema portugal using three different dosages showed that the spores of $N$. portugal had lost infectivity after storage in liquid nitrogen for 18.75 years; none of the tested larvae was infected. In contrast, spores of Nosema sp. (Ebergassing) had retained infectivity after 18.75 years of

Table 2. Infection of $L$. dispar larvae after treatment with $1 \mu$ of three different dosages of Nosema portugal and Nosema sp. (Ebergassing) Tablica 2. Zaraza ličinki L. dispar nakon pokusa individualne aplikacije različitih doza sporama Nosema portugal i Nosema sp. (Ebergassing)

$\begin{array}{cccc}\text { Isolate } & \begin{array}{c}\text { Spore } \\ \text { concentration } \\ \text { Izolat }\end{array} & \begin{array}{c}\text { Number } \\ \text { of the tested }\end{array} & \begin{array}{c}\text { Percent } \\ \text { larvae } \\ \text { Infected (\%) }\end{array} \\ & \text { Koncentracija } & \text { Broe } & \text { Postotak } \\ & \text { spora } & \text { testiranih } & \text { zaraženih } \\ & (\mathrm{sp} / \mu \mathrm{l}) & \text { ličinki } & \text { ličinki }(\%)\end{array}$

Nosema portugal

$\begin{array}{ccc}100 & 48 & 0 \\ 1000 & 47 & 0 \\ 10000 & 44 & 0\end{array}$

Nosema sp. Ebergassing

$\begin{array}{ccc}100 & 46 & 0 \\ 1000 & 48 & 4.1 \\ 10000 & 48 & 68.8\end{array}$


storage: None of the 48 tested larvae was infected after ingestion of 100 spores. However, dosages of 1000 spores per larva led to infections of $4.1 \%$ of the tested larvae becoming infected; and when applying 10000 spores per larva, 68.8\% were infected (Table 2). In all cases, the infections at the end of the incubation period were heavy and the infected fat body was filled with spores.

\section{DISCUSSION}

\section{RASPRAVA}

Maddox and Solter (1996) investigated the viability of 31 species of microsporidia, isolated from terrestrial insects and stored in liquid nitrogen for up to 25 years and reported that all species were able to produce infections in hosts from six insect orders. In their experiments, the only microsporidium isolated from Lymantria dispar was Endoreticulatus schubergi which was stored for 9 years in liquid nitrogen. This species is very different from the Nosema and Vairimorpha species used in our study in many aspects, such as spore survival under winter conditions (Goertz and Hoch 2008). We demonstrated that V. disparis and N. lymantriae can survive 7 years of storage in liquid nitrogen.

Nosema sp. (Ebergassing) survived for even more than 18 years. However, spore viability was clearly reduced. Dosages of 1000 spores per larva caused infections in only $4.1 \%$. The same dosage of spores stored in liquid nitrogen no longer than 2 months caused $100 \%$ infections in experiments using the same method of inoculation (G. Hoch, unpublished data). When spores of Nosema sp. (Ebergassing) in concentrations of $1 \times 10^{3}$ spores $/ \mu \mathrm{l}$ and $1 \times 10^{5}$ spores $/ \mu$ stored for less than a year in liquid nitrogen were used for surface contamination of diet fed to $L$. dispar larvae, $95 \%$ of the larvae fed with the lower concentration spores and $100 \%$ of the larvae fed with the higher concentration were infected (Hoch, 1999).

Hoch et al. $(2004 ; 2009)$ also conducted individual inoculations of $L$. dispar larvae with $1 \times 10^{4}$ spores of Nosema portugal stored in liquid nitrogen for no longer than 2 months. The results showed high larval mortality (almost 100\%) of the larvae caused by this microsporidium. In our experiments, even dosages of $1 \times 10^{5}$ spores or high concentrations for surface contamination did not cause any infection, which shows that the spores of Nosema portugal spores lost their viability infectivity after 18 -year long-term storage in liquid nitrogen.

Goertz et al. (2004) performed infection experiments with spores of Nosema sp. (Veslec) stored in liquid nitrogen for less than 7 years. The authors used five spore dosages per larva $\left(2 \times 10^{2}, 1 \times 10^{3}, 5 \times 10^{3}, 1 \times 10^{4}\right.$ and $\left.5 \times 10^{4}\right)$ for individual infections. The experimental infection rates ranged between $97-100 \%$, when third instar larvae were fed in dosages ran- ging from $1 \times 10^{3}$, to $5 \times 10^{4}$ spores. The low dosage of $2 \times 10^{2}$ spores resulted in an infection rate of $77 \%$.

The results from our experiments with spores used in surface contamination showed that Nosema sp. (Veslec) lose their viability and infectivity after storage for 11 years in liquid nitrogen. Spores of Nosema sp. (Schweinfurth), stored for 7 years in liquid nitrogen, also did not cause infections when fed to $L$. dispar larvae via surface contamination.

\section{CONCLUSIONS ZAKLJUČCI}

Our study confirms that storage in liquid nitrogen is a suitable option for long-term storage of Nosema and Vairimorpha species from lepidopteran hosts. Spores of some isolates survived for more than 18 years; however, the experiments show that there is a significant loss of viability. Spores of some isolates had lost viability already after 7 years in liquid nitrogen. Therefore, it is recommended to produce fresh material every 5 years to maintain collections. Based on our experiments or field application, no material should be used that had been stored in liquid nitrogen for period longer than five years. Liquid nitrogen storage offers the opportunity to produce and maintain large quantities of homogenous microsporidian inoculum for experiments and inoculative biocontrol releases.

\section{ACKNOWLEDGEMENTS}

\section{ZAHVALA}

- The authors would like to thank to the German Academic Exchange Service (DAAD) for supporting this research.

- References - LITERATURA

- Bjornson, S., D. Oi, 2014: Microsporidia biological control agents and pathogens of beneficial insects. In: (Eds: L.M. Weiss and J.J. Becnel), Microsporidia: Pathogens of Opportunity, 1. ed., 635-67, John Wiley \& Sons, Inc.

- Goertz, D., D. Pilarska, M. Kereselidze, L.F. Solter, A. Linde, 2004: Studies on the impact of two Nosema isolates from Bulgaria on the gypsy moth (Lymantria dispar L.). Journal of Invertebrate Pathology, 87: 105-113.

- Goertz, D., G. Hoch, 2008: Vertical transmission and overwintering of microsporidia in the gypsy moth, Lymantria dispar. Journal of Invertebrate Pathology, 99: 43-48.

- Hoch, G., 1999: Wechselwirkungen zwischen einer entomopathogenen Mikrosporidie und dem Endoparasitoiden Glyptapanteles liparidis in ihrem gemeinsamen Wirt, der Lymantria dispar Larve. Ph.D. thesis, Universität für Bodenkultur, Wien, $64 \mathrm{p}$.

- Hoch, G., M. Zubrik, J. Novotny, A. Schopf, 2001: The natural enemy complex of the gypsy moth, Lymantria dispar (Lep., Lymantriidae) in different phases of its population dynamics in eastern Austria and Slovakia - a comparative study. Journal of Applied Entomology 125, 217-227.

- Hoch, G., L.F. Solter, A. Schopf, 2004: Hemolymph melanization and alterations in hemocyte numbers in Lymantria dispar 
larvae following infections with different entomopathogenic microsporidia. Entomologia Experimentalis et Applicata, 113: 7786.

- Hoch, G., L.F. Solter, A. Schopf, 2009: Treatment of Lymantria dispar (Lepidoptera, Lymantriidae) host larvae with polydnavirus/venom of a braconid parasitoid increases spore production of entomopathogenic microsporidia. Biocontrol Science and Technology, 19: 35-42.

- Hoch, G., L.F. Solter, 2018: Micrsporidia. In: Ecology of Invertebrate Diseases (Ed: A. Hajek), 379-413, John Wiley \& Sons, Inc.

- Jeffords, M.R., J.V. Maddox, M.L. McManus, R.E. Webb, A. Wieber, 1988: Egg contamination as a method for the inoculative release of exotic microsporidia of the gypsy moth. Journal of Invertebrate Pathology, 51, 190-196.

- Jeffords, M.R., J.V. Maddox, M.L. McManus, R.E. Webb, A. Wieber, 1989: Evaluation of the overwintering success of two European microsporidia inoculatively released into gypsy moth populations in Maryland. Journal of Invertebrate Pathology, 53, 253-240

- Maddox, J., L.F. Solter, 1996: Long-term storage of infective microsporidian spores in liquid nitrogen. Journal of Eukaryotic Microbiology, 43: 221-225.

- McManus, M.L., L. F. Solter, 2003: Microsporidian pathogens in European gypsy moth populations. Proceedings: Ecology, Survey and Management of Forest Insects GTR-NE-311, 44-51.

- Novotny, J. 1989: Bioregulovanie pocetnosti mnisky velkohlavej. Lesnícke Štúdie. Bratislava, 107 pp.

- Pilarska, D.K, L.F. Solter, J., Maddox, M. McManus, 1998: Microsporidia from gypsy moth (Lymantria dispar L.) populations in Central and Western Bulgaria. Acta zoologica bulgarica, 50: 109-113.

- Pilarska, D.K., L.F. Solter, M. Kereselidze, A. Linde, G. Hoch, 2006: Microsporidian infections in Lymantria dispar larvae: Interactions and effects of multiple species infections on pathogen horizontal transmission. Journal of Invertebrate Pathology, 93: 105-113

- Pilarska D., A. Linde, P. Pilarski, G., Georgiev, D. Takov, L. F. Solter, 2010: Release of Nosema lymantriae, Vairimorpha disparis and Entomophaga maimaiga for classical and augmentative biological control of gypsy moth in Bulgaria and the United States. Proceedings of 43th Annual Meeting of the Society for Invertebrate Pathology, Trabzon, Turkey, Symposium Microsporidia "Microsporidia and other pathogens in arthropods from the Eastern Mediterranean region", 11-15.07.2010, Trabzon, Turkey, CD, 1-6.

- Pilarska, D.K., D. Takov, M. Hylis, R. Radek, I. Fiala, L. Solter, A. Linde, 2017: Natural oocurrence of microsporidia infecting Lepidoptera in Bulgaria. Acta Parasitologica, 62 (4): 858-869.

- Solter, L.F., D.K. Pilarska, C.F. Vossbrinck, 2000: Host specifity of microsporidia pathogenic to forest Lepidoptera. Biological Control, 19: 48-56.

- Solter, L.F, D.K. Pilarska, M. L. McManus, M. Zubrik, J. Patocka., W. F. Huang, J. Novotny, 2010: Host specificity of microsporidia pathogenic to the gypsy moth, Lymantria dispar (L.): Field studies in Slovakia. Journal of Invertebrate Pathology, 105: 1-10.

- Solter, L.F., Becnel, J.J., Oi, D.H. 2012. Microsporidian entomopathogens. In: Insect Pathology, Second Edition. (Eds: F.E. Vega and H.K. Kaya), Elsevier, San Diego. Pp. 221-263.

- Vavra, J., M. Hylis, C. Vossbrinck, D.K. Pilarska, A. Linde, J. Weiser, M. McManus, G. Hoch, L.F. Solter, 2006: Vairimorpha disparis n. comb. (Microsporidia: Burenellidae): a redescription and taxonmic revision of Thelohania disparis Timofejeva 1956, a microsporidian parasite of the gypsy moth Lymantria dispar (L.) (Lepidoptera: Lymantriidae). Journal of Eukaryotic Microbiology, 53: 292-304.

- Weiser, J., Novotny, J. 1987: Field application of Nosema lymantriae against the gypsy moth, Lymantria dispar L. Journal of Applied Entomology, 104(1-5): 58-62.

\section{SAŽETAK}

U radu se prikazuju rezultati preživljenja mikrosporidija izoliranih iz gubara (Lymantria dispar) nakon dugotrajne pohrane u tekućem dušiku. Infektivnost osam mikrosporidijskih $L$. dispar izolata testirano je na ličinkama gubara: Vairimorpha disparis, Nosema lymantriae, Nosema portugal, Nosema sp. (Poljska), Nosema sp. (Ebergassing), Nosema sp. (Njemačka), Nosema sp. (Schweinfurt) and Nosema sp. (Veslec). Preživljenje spora u tekućem dušiku detaljno je praćeno kod N. portugal i Nosema sp. (Ebergassing) koje su tako čuvane skoro 19 godina i aplicirane oralnom infekcijom i ponaosob na svaku pojedinu ličinku gubara. Ostalih 6 izolata aplicirano je površinskom kontaminacijom hranjivog supstrata, također oralnim infekcijskim putem. Od 8 mikrosporidijskih izolata apliciranih površinskom kontaminacijom samo kod 4 izolata, Vairimorpha disparis, Nosema lymantriae, Nosema sp. (Ebergassing) i Nosema sp. (Poljska), došlo je do uspješne infekcije ličinki gubara. Dok je kod svih testiranih ličinki (100\%) uspješno realizirana infekcija sporama prve tri mikrosporidije, tek $21,1 \%$ tretiranih ličinki uspješno je inficirano sporama Nosema sp. (Poljska). Na kraju inkubacijskog razdoblja, kod svih ličinki inficiranih sa sva 4 izolata disekcijom je utvrđen visok stupanj zaraze; tkiva su bila ispunjena sporama. Mikroskopska pretraga ličinki L. dispar individualno tretiranih sporama Nosema portugal uz tri različite doze (100, 1000 i 10000 spora) pokazala je da su spore N. portugal izgubile infektivnost nakon 19 godina pohrane u tekućem dušiku; niti jedna od testiranih ličinka nije bila zaražena. Naprotiv, spore Nosema sp. (Ebergassing) zadržale su infektivnost nakon istog razdoblja pohrane u tekućem dušiku od 18,75 godina. Niti jedna od testiranih ličinki nije zaražena nakon oralnog unosa od 100 
spora. Oralna aplikacija od 1000 spora po ličniki rezultirala je ukupnom uspješnom infekcijom 4,1\% ličinki, a aplikacija od 10000 spora s 68,8\% inficiranih ličinki. U svim uspješnim slučajevima uspješno zaraženih ličinki, na kraju inkubacijskog razdoblja infekcija je bila dobro razvijena, a masno tijelo prepuno spora. Istraživanje je potvrdilo da je pohrana mikrosporidija Nosema i Vairimorpha vrsta i domaćina iz reda leptira prikladna opcija za dugotrajno čuvanje izolata. Spore su preživjele i do $18 \mathrm{i}$ pola godina, iako je tijekom eksperimenta zamijećen i značajan pad njihove infektivnosti. U pojedinim slučajevima spore su odumrle već nakon 7 godina pohrane u tekućem dušiku. Preporuka je da prilikom skladištenja i pohrane mikrosporidijskih izolata u tekućem dušiku svakih 5 godina repozitorij obnavlja svježim izolatima. Materijal koji se dulje vrijeme skladišti u tekućem dušiku nije prikladan i ne bi se smio koristiti u infektološkim testovima.

KLJUČNE RIJEČI: mikrosporidija, vitalnost spora, dugotrajna pohrana, tekući dušik 